\title{
Scutellaria baicalensis and Their Natural Flavone Compounds as Potential Medicinal Drugs for the Treatment of Nicotine-Induced Non-Small-Cell Lung Cancer and Asthma
}

\author{
Naser A. Alsharairi (D)
}

Citation: Alsharairi, N.A. Scutellaria baicalensis and Their Natural Flavone Compounds as Potential Medicinal Drugs for the Treatment of NicotineInduced Non-Small-Cell Lung Cancer and Asthma. Int. J. Environ. Res. Public Health 2021, 18, 5243. https:// doi.org/10.3390/ijerph18105243

Academic Editor: Paul B. Tchounwou

Received: 23 March 2021

Accepted: 13 May 2021

Published: 14 May 2021

Publisher's Note: MDPI stays neutral with regard to jurisdictional claims in published maps and institutional affiliations.

Copyright: (C) 2021 by the author Licensee MDPI, Basel, Switzerland. This article is an open access article distributed under the terms and conditions of the Creative Commons Attribution (CC BY) license (https:// creativecommons.org/licenses/by/ $4.0 /)$
Heart, Mind \& Body Research Group, Griffith University, Gold Coast, QLD 4222, Australia; naser.alsharairi@gmail.com

\begin{abstract}
Flavonoids as the largest group of natural phytochemical compounds have received significant attention, as demonstrated by clinical trials, due to their chemotherapeutic and/or pharmacological effects against non-small-cell lung cancer (NSCLC) and asthma. Scutellaria baicalensis (S. baicalensis), known as one of the most popular medicinal plants and used in several countries, contains natural active flavone constituents, with the major compounds of the roots being baicalein, baicalin, wogonin, wogonoside and oroxylin A. S. baicalensis and their compounds are proven to have inhibitory effects on NSCLC cells when used at different concentrations. However, the exact mechanisms by which these compounds exert their therapeutic effects against asthma remain unexplored. Indeed, the mechanisms by which S. baicalensis and its flavone compounds exert a protective effect against nicotine-induced NSCLC and asthma are not yet fully understood. Therefore, this review explores the mechanisms involved in the therapeutic potential of flavone-rich extracts from S. baicalensis in nicotine-induced NSCLC and asthma.
\end{abstract}

Keywords: Scutellaria baicalensis; flavone compounds; nicotine; NSCLC; asthma

\section{Introduction}

Lung cancer is regarded as the most common cause of cancer-related mortality worldwide [1] and is mostly caused by malignant tumors [2]. Lung cancer consists of two main types: small cell lung cancer (SCLC) and non-small-cell lung cancer (NSCLC), with the latter comprising $85 \%$ of all lung cancer cases, and including three smoking-related subtypes; squamous, adenocarcinoma and large cell carcinoma [3]. Globally, more than $64 \%$ of lung cancer mortality is attributed to tobacco smoking [4]. Nicotine as the major addictive and toxic chemical ingredient in cigarette smoke increases risk of developing NSCLC [5-7]. Nicotine and cigarette smoke extract (CSE) are involved in inducing Epithelial-to-Mesenchymal Transition (EMT) through epigenetic change and histone deacetylase (HDAC)-mediated downregulation of epithelial (E)-cadherin and increasing expression of the mesenchymal markers metalloproteinase 9 (MMP9), vimentin, fibronectin and neural (N)-cadherin in NSCLC cell line A549, leading to lose adhesions/junctions and polarity in epithelial cells [8-10].

In NSCLC, tumor cell interaction with immune system is controlled by a network of biological signaling pathways [11,12]. T-cells responses have been observed against NSCLC tumor-associated antigens (TAA) (e.g., MAGE-A1, PRAME, MUC1) in NSCLC cell lines [13], which may result in activation of inhibitory immune checkpoint pathways/molecules such as programmed death-1 (PD-1), programmed death-ligand 1 (PD-L1) and cytotoxic Tlymphocyte-associated protein 4 (CTLA-4), in what are known as markers for exhausted $\mathrm{T}$ cells [12]. Upon the activation of antigen, the histocompatibility complex (MHC) class I and II molecules on antigen-presenting cell (APC) present tumor antigens to the T-cell receptor (TCR), resulting in an activation of TAA-specific CD8+ cytotoxic T cells and CD4+ helper $\mathrm{T}$ cells. Inhibitory immune checkpoint pathways are expressed on regulatory $\mathrm{T}$ cells 
$\left(\mathrm{T}_{\text {regs }}\right)$ after their upregulation, and function as immunosuppressive of CD8+ and CD4+ T cells via further production of pro-inflammatory cytokines, including interleukin (IL)-10 and transforming growth factor $\beta$ (TGF $\beta$ ) [12].

Asthma is a chronic inflammatory disease in which airway smooth muscle (ASM) contributes to asthma through airway wall thickening, hyperresponsiveness and remodeling, impaired relaxation and persistent airflow obstruction [14]. There have been studies indicating that smoking is a potential risk factor for asthma, and the risk of asthma appears to increase among smokers [15]. Nicotine is thought to play a key role in the development of asthma in adult smokers [16]. Asthma is regarded as a contributing factor in lung cancer, and the risk of NSCLC is increased greatly in asthmatic smokers [17].

Several systemic treatments for inoperable NSCLC exist including, chemotherapy, immunotherapy and molecular targeted therapies, while surgery and radiation are used in patients with locally advanced [18]. NSCLC is still the leading cause of death, despite the prominent progress in the prognosis over the last years [1]. Monoclonal antibodies such as atezolizumab, nivolumab, pembrolizumab and bevacizumab targeting inhibitory immune checkpoint molecules have shown novel immunotherapies agent in locally advanced NSCLC [11,19]. Treatment with chemotherapeutic agents (e.g., cisplatin) in combination with monoclonal antibodies may provide benefits in patients with metastasized stage NSCLC $[19,20]$. Therapeutic agents such as afatinib, osimertinib, gefitinib and erlotinib have shown promising results in patients with NSCLC who have driver mutations such as epidermal growth factor receptor (EGFR) and anaplastic lymphoma kinase (ALK) [19]. Pycnogenol and quercetin have been widely used in asthma treatment, since they are found to suppress inflammatory cytokine production and airway hyperresponsiveness [21]. With several dietary supplements available in a global market, there is still a research gap on their efficacy and safety to treat lung cancer, particularly among asthmatic smokers, given inconsistent results in clinical trials, with no benefits, and in fact, it has been shown that they may cause harm in long-term use [21,22]. Therefore, promising therapeutic agents with low toxicity and high efficacy in targeting NSCLC and asthma in patients are needed.

Flavonoids are the major group of natural plant-derived compounds with polyphenolic structure, and are largely present in grains, flowers, roots, seeds, fruits, vegetables and drinks (including wine, cocoa and tea) [23]. Flavonoids are categorized into distinct classes depending on their chemical structure, with a fifteen-carbon skeleton comprising of two aromatic benzene rings (A and $\mathrm{B}$ ) and connected by a third heterocyclic pyrane ring (C) [24]. Major classes include isoflavones (e.g., genistein, genistin, glycitein, daidzein, daidzin), flavanonol (e.g., taxifolin), flavanones (e.g., naringenin, naringin, hesperidin, hesperitin, abyssinones, eriodictyol), flavonols (e.g., galangin, quercetin, myricetin, rutin, morin, fisetin, kaempferol), flavones (e.g., chrysin, diosmetin, tricin, luteolin, apigenin, baicalin, baicalein, tangeretin, rpoifolin), flavan-3-ols (e.g., epicatechin gallate, catechin), anthocyanidins (e.g., petunidin, pelargonidin, delphinidin, peonidin, malvidin) and chalcones (e.g., phlioridzin, chalconaringenin, phloretin, arbutin) [23,24]. The substitution and/or configuration patterns of the hydroxyl groups in the flavonoid classes A, B- or C-rings may impact their biological activities, particularly in terms of antioxidant, antibacterial, antiviral and anti-inflammatory properties and modulation of major enzymatic pathways, which are considered key mechanisms through which these classes could exert chemopreventive effects against cancer [23-25]. A recent review showed that flavones, and apigenin, diosmetin and luteolin in particular, act as anti-lung cancer drugs, which have a wide range of molecular mechanisms for the prevention and/or treatment of NSCLC cells. The main mechanisms include (1) suppression of receptor tyrosine kinase (RTK), which is able to mediate activation of cellular signaling pathways, leading to the promotion of lung cancer tumor growth, (2) suppression of proliferation in lung cancer cells, (3) induction of apoptosis and cell cycle arrest through activation of protein 53 (p53) expression and inhibition of key transcription factors, and (4) attenuation of the invasion/migration and metastasis of NSCLC cells through inhibition of the EMT [26]. A recent study on NSCLC cell line A549 after treatment with luteolin demonstrated significant suppression of the 
migration/invasion and filopodia formation, with no cytotoxic activity in cells observed. The effect of luteolin is induced via down-regulating expression of the focal adhesion kinase (FAK) and non-receptor tyrosine kinase (Src) downstream pathways, including the Ras homolog gene family member A (RhoA), cell division control protein 42 (Cdc42) and Ras-related C3 botulinum toxin substrate 1 (Rac1) [27].The natural flavone luteolin has been reported to suppress mast cells (MCs) that mature in human tissues and are implicated in asthma. Luteolin is significantly suppressed immunoglobulin E ( $\operatorname{IgE}) /$ anti-IgE-induced histamine, beta-hexosaminidase ( $\beta$-hex) and tumor necrosis factor (TNF)- $\alpha$ production from laboratory of allergic diseases 2 (LAD2) human MCs. The potential mechanisms underlying the anti-inflammatory action of luteolin involve inhibiting nuclear transcription factor-kappaB (NF-kB) activation and intracellular calcium increase [28].

There has been an increased interest in ascertaining the significance of medicinal plants in the treatment of diseases, given the high content of flavonoid compounds in these plants [24]. Medicinal plants have proven clinical efficacy for the treatment of a plethora of diseases such as cardiovascular disease [29], neurodegenerative disorders [30] and rheumatoid arthritis [31]. Medicinal plants have also been proven to be effective in asthma [32] and NSCLC treatment [33]. However, a significant number of medicinal plants can produce toxic side effects and their safety for use by patients is uncertain [34-36]. Therefore, further studies are needed to find potent medicinal plants useful for NSCLC and asthma treatment with few or no side effects.

Scutellaria baicalensis Georgi (S. baicalensis), also known as Chinese skullcap orHuangQin, is a traditional Chinese medicinal plant that belongs to the family Lamiaceae and is widely used in East Asian countries, Russia, Europe and North America as an adjuvant to chemotherapy for many diseases [37-39]. Flavonoids and their glycosides are the major bioactive chemical compounds of $S$. baicalensis, with the main constituents of the root-specific 4'-deoxyflavones (known as Scutellariae radix, S. radix) being baicalein, baicalin, wogonin, wogonoside and oroxylin A $[38,39]$. These flavones exert anti-tumor functions against various types of cancer, including brain, prostate and oral squamous cell carcinoma (SCC) [40], and have been recorded in Chinese and European Pharmacopoeia as being medicinal drugs used to treat several diseases [39]. Previous studies are still insufficient to understand the effect of flavone compounds in NSCLC treatment in vivo. Studies in mice showed that A549 and H-460 cells treated with S. baicalensis compounds (baicalin, baicalein and wogonin) result in inhibition of cell proliferation and angiogenesis by downregulating expressions of inhibitors of differentiation 1 (Id1) protein, EMT-related molecules (N-cadherin, vimentin), vascular endothelial growth factor A (VEGF-A) and fibroblast growth factor receptor 2 (FGFR2) through suppression of the Src/Id1 signaling pathway [41-43]. The molecular effect and mechanism of action of $S$. baicalensis and its compounds at different concentrations showed strong inhibitory properties in NSCLC cells, as reported by in vitro studies. However, the potential molecular mechanisms by which S. baicalensis and its isolated compounds are thought to be useful in the treatment of asthma have not been clearly studied. Indeed, the mechanisms of the anti-lung cancer and asthma action of $S$. baicalensis containing flavones compounds in nicotine-induced NSCLC and asthma are unclear. The significant link between NSCLC and asthma could have health benefits for smokers in terms of using S. baicalensis and its compounds. Given that $S$. baicalensis is used in several therapeutic practices, targeting the flavones extracted from such a plant and understanding its molecular mechanisms of action might help in providing new therapeutic strategies for the treatment of NSCLC and asthma, particularly in smoker patients. To date, there are no reviews which discuss the mechanisms of S. baicalensis and their compounds involved in nicotine-induced NSCLC and asthma treatment. Therefore, this review attempts to provide a detailed overview of the mechanisms of flavones extracted from S. baicalensis and explore its therapeutic potential in nicotine-induced NSCLC and asthma. 


\section{Methods}

A literature search was undertaken to retrieve studies published in English and carried out over the last 10 years, using the PubMed/MEDLINE database and the following search words: "Scutellaria baicalensis" or "Scutellariae radix" or "baicalein" or "baicalin" or "wogonin" or "wogonoside" or "oroxylin A" and "lung cancer" or "NSCLC" and "asthma" and "smoking" or "nicotine". Studies on S. baicalensis/S. radix and their compounds are included if they have been tested for anti-NSCLC and asthma efficacy. The search is limited to experimental in vitro studies. In total, 216 articles were extracted using the search terms. As a result, 29 studies were selected based on the search criteria.

\section{In Vitro Effects of Nicotine on NSCLC Development}

Nicotine as the main addictive and harmful chemical constituent of cigarette smoke plays a key role in lung carcinogenesis [5-7], which enhances proliferation, invasion, cell cycle progression, angiogenesis, and inhibition apoptosis through activation of the a7 subunit of the nicotine acetylcholine receptor (a7nAChR)-mediated signaling pathways implicated in NSCLC development [44-46]. Activation of nicotine- $\alpha 7 \mathrm{nAChR}$ promotes cell invasion/proliferation in NSCLC cells, and EMT which is a key step in altering the malignant phenotype of cancer cell lines, resulting in suppression of E-cadherin and induction of MMPs, vimentin, fibronectin and $\mathrm{N}$-cadherin expression [8-10]. Upregulation of several transcription and growth factors such as TGF $\beta$, Snail, twist, deca-pentaplegic homolog (Smad) and cyclinD1, as well as hypoxia-inducible factors (e.g., HIF-1 $\alpha$ ) induce EMT in NSCLC cells via activation of the Notch signaling pathway $[47,48]$. The $\alpha 7 \mathrm{nAChR}$ expression level has been revealed to be higher in SCC compared to other NSCLC types, particularly in smokers [46]. Nicotine-specific nitrosamines, including $\mathrm{N}^{\prime}$-nitrosonornicotine (NNN) and 4-(metylnitrosamino)-1-(3-pyridyl)-1-butanon (NNK) have the most carcinogens in cigarette smoke, which in turn after binding to $\alpha 7 \mathrm{nAChR}$ and nicotinic acetylcholine receptors ( $\beta$-AR) (e.g., adrenaline and noradrenaline) activate the EGFR/serine-threonine kinase (EGFR/Akt) signaling pathway involved in anti-apoptosis, which contributes to NSCLC progression in smokers [49]. The nicotine-mediated activation of $\alpha 7 \mathrm{nAChR}$ and its downstream signaling pathways are involved in several functions, as reported by in vitro studies $[46,49,50]$. Table 1 shows the functions of nicotine $/ \alpha 7 \mathrm{nAChR}$-mediated NSCLC development.

Table 1. Major functions of nicotine/ $\alpha 7 \mathrm{nAChR}$ in NSCLC development.

\begin{tabular}{|c|c|}
\hline Functions & $\alpha 7 n A C h R-A s s o c i a t e d$ Signalling Pathways in NSCLC \\
\hline $\begin{array}{l}\text { Cell } \\
\text { proliferation }\end{array}$ & 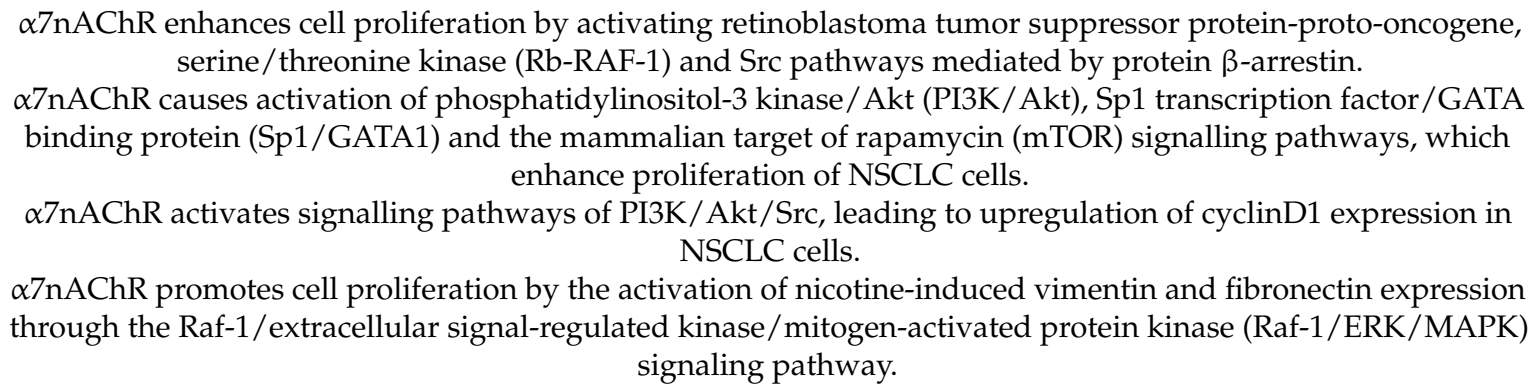 \\
\hline Metastasis & $\begin{array}{c}\alpha 7 \mathrm{nAChR} \text { stimulates migration and invasion of NSCLC cells by activating the ERK/MAPK, Src/protein kinase } \\
\mathrm{Cl} / \mathrm{FAK} \text { (Src/PKCl/FAK), PI3K and Yes-associated protein-E2F transcription factors 1 (YAP-E2F1) } \\
\text { signaling pathways. }\end{array}$ \\
\hline Angiogenesis & $\begin{array}{c}\text { Upregulation of } \alpha 7 \mathrm{nAChR} \text { in NSCLC cells promotes angiogenesis via activation of } \mathrm{Ca}^{2+} \text { influx, which stimulates } \\
\text { signaling pathways including VEGF-A, NF- } \mathrm{B}, \mathrm{PI} 3 \mathrm{~K} / \mathrm{AKT} \text { and FGFR2. }\end{array}$ \\
\hline Anti-apoptosis & $\begin{array}{l}\alpha 7 \mathrm{nAChR} \text { suppresses apoptosis in nicotine-induced NSCLC cells by activating the PI3K/Akt pathway, which } \\
\text { inhibits proapoptotic Bcl-2-associated X protein (Bax) expression. } \\
\text { Nicotine upregulates the protein expression of B-cell lymphoma-2 (Bcl-2) through } \alpha 7 \mathrm{nAChR} \text {-mediated } \\
\text { activation of the Raf-1/MAPK signaling pathway, which leads to phosphorylation of transcription factor c-myc, } \\
\text { resulting in significantly inhibited apoptosis in NSCLC cells. }\end{array}$ \\
\hline
\end{tabular}




\section{Therapeutic Role of Scutellaria baicalensis and Their Flavone Compounds in Nicotine-Induced NSCLC}

This section presents the therapeutic role of $S$. baicalensis and their flavone compounds in nicotine-induced NSCLC.

S. baicalensis and its extracts possess anti-lung cancer activity demonstrated in NSCLC cells. Park et al. [51] showed that the aqueous extract of $S$. baicalensis root inhibits cell motility/proliferation and induces G1 phase arrest, with no cytotoxicity against A549 cells observed. S. baicalensis downregulates cyclinD1, cyclin-dependent kinase 4 (CDK4) and MMP2 production in A549 cells. Kim et al. [52] reported that the aqueous extract of S. radix induces apoptosis by increasing caspase 3, Poly ADP ribose polymerase (PARP) cleavage, and phospho-AMP-activated protein kinase (AMPK) and reducing mTOR in H2087 and H358 cells. S. radix also induces autophagy via increasing microtubule-associated protein 1A/1B-light chain 3 (LC3)-II/LC3-I expression. A study by Wang et al. [53] assessed the anti-lung tumor effect of $S$. radix ethanolic extracts on cell invasion and proliferation of A549 cells. The extracts (baicalein, wogonin) cause invasion and proliferation inhibitory effects on A549 cells and arrest the cell cycle at S phase via downregulating expression of cyclinD1 and upregulating expression of p53.

Gao et al. [54] studied the anti-lung cancer effect of S. baicalensis ethanolic extracts (baicalein, baicalin, wogonin) on NSCLC cells. Cytotoxicity analysis has demonstrated strong activity against cell lines SK-LU-1, A549 and SK-MES-1. The cytotoxicity of S. baicalensis is reported as high against A549 and SK-LU-1 cells due to the stochiometric combination of extracts. The extracts reported cell cycle and apoptosis-inducing in NSCLC cells via upregulating expressions of p53 and Bax and downregulating expressions of cyclinA. The study concludes that the cytotoxicity of extracts may control growth of NSCLC cells via inducing cell cycle arrest and apoptosis, suggesting the significance of cell growth arrest and apoptosis as potential mechanisms in the cytotoxicity of flavones treatment. Gong et al. [55] studied the apoptotic and anti-inflammatory effects of baicalin, baicalein and wogonin extracted from S. baicalensis on nicotine-induced A549 and H1299 cells. The extracts upregulate expression of Bax and downregulate expressions of MMP2, MMP9, caspase-3, bcl-2/bax ratio and bcl-2. The extracts showed anti-inflammatory activity by inhibiting expressions of NF- $k$ B, TNF- $\alpha$, IL- 6 and I kappa B-alpha (I $\kappa \mathrm{B}-\alpha$ ) in NSCLC cells. Zhao et al. [41] reported the effects of three major S. baicalensis extracts: baicalein, baicalin and wogonin on A549 and H1299 cells. The extracts inhibit growth, and the invasive and migratory activities of NSCLC cells. The extracts suppress expressions of VEGF-A, $\mathrm{N}$-cadherin and vimentin through Akt/Src signaling pathway blocking.

\subsection{Baicalein}

Baicalein has been reported to promote apoptosis and/or suppress cellular growth and proliferation of NSCLC cells. A study has shown that baicalein promotes sensitivity to cisplatin drugs in A549 and H460 cells by inducing apoptosis and inhibiting cell proliferation through suppression of the PI3K/Akt signaling pathway and the expression of microRNA 424-3p (miR-424-3p) targeting phosphatase and tensin homolog (PTEN) gene expression [56]. In another study, baicalein enhances antitumor activity by reducing the induction of vasculogenic mimicry (VM), a pattern of tumor microcirculation, via inhibiting the expression of VM-associated factors (e.g., MMP9, VE-cadherin) and the RhoA/rhoassociated coiled-coil kinase (RhoA/ROCK) signaling pathway, leading to the suppression of motility and viability of A549 cells [57]. A study by Li et al. [58] reported that baicalein suppresses MAP4K3 expression via reducing its stability. The results also indicated that inhibition of the mTOR signaling pathway in A549 and H1299 cells by RNA interference could be sufficient in mediating baicalein-induced autophagy.

In a study carried out by Zhang et al. [59], the A549 and H1299 cells were treated with different concentrations of baicalein to study the mechanisms by which baicalein suppresses cell metastasis. The results showed that baicalein inhibits cell metastasis by inhibiting ezrin tension transduction, leader cell production and inducible nitric oxide 
synthase (iNOS)-mediated ezrin S-nitrosylation (SNO) tension, which are responsible for A549 and H1299 cell aggression in the inflammatory milieu. A study by Cathcart et al. [42] reported that the angiogenesis of NSCLC cells (A549, H460 and SKMES1) is significantly inhibited via downregulating VEGF-A, FGFR-2 and RB-1 expression. Su et al. [60] reported baicalein increases the protein expression of E-cadherin and inhibits the EMT-induced $\mathrm{N}$-cadherin and vimentin in A549 and H1299 cells by downregulating the Notch signaling pathway. Similarly, a study on the anti-tumor effect of baicalein on NSCLC cells showed that baicalein causes an inhibitory effect on A549 cells by suppressing the expressions of $\mathrm{N}$-cadherin, vimentin, VEGF-1, and upregulating the expression of E-cadherin through Src-Id1 signaling pathway blocking [43]. Therefore, baicalein showed effective results in the inhibition of NSCLC cells through anti-proliferative/metastatic, anti-angiogenesis and apoptosis/autophagy induction. The mechanisms underlying the effect are linked to the inhibition of different cellular signaling pathways.

\subsection{Baicalin}

A few in vitro studies have shown potent anti-lung cancer activity of baicalin in NSCLC cell lines. Zhang et al. [61] reported the anti-lung cancer activities of baicalin in A549 and H2009 cells at different concentrations, in combination with tumor necrosis factorrelated apoptosis-inducing ligand (TRAIL), a potential anticancer agent which modulates signaling pathways in NSCLC cells. Baicalin sensitizes lung cancer cells to TRAIL-induced apoptosis via the activation of MAPK and reactive oxygen species (ROS) production. Another study reported a high anti-lung cancer effect of baicalin in combination with DDP (cisplatin) on proliferation and invasion of A549 cells. Baicalin suppresses protein expression of microtubule affinity-regulating kinase 2 (MARK2) and Akt in A549/DDP cells, which are involved in cell proliferation and the pathogenesis of lung cancer [62]. Diao et al. [63] used baicalin to examine its inhibitory effect on NSCLC cells. The inhibitory effect of baicalin is observed against H441, H1975 and H1299 cells with a high expression level of PDZ-binding kinase/T-LAK cell-originated protein kinase (PBK/TOPK), a novel mitotic kinase which promotes cell invasion. You et al. [64] reported that baicalin stimulates apoptosis and inhibits the invasion abilities in A549 and H1299 cells. This is observed through activation of the sirtuin 1 gene/AMPK (SIRT1/AMPK) signaling pathway, known as tumor suppressor genes, and inhibition of the expression levels of MMP2 and MMP9 in NSCLC cells. From these studies, it can be suggested that baicalin has significant antiproliferative/invasive and apoptotic effects, and the mechanisms of its therapeutic effect in NSCLC cells are related to the modulation of cellular signaling pathways.

\subsection{Wogonin}

Wogonin possesses antitumor properties against NSCLC cells, as demonstrated by a few in vitro studies. The study conducted by He et al. [65] found high anti-tumor activity against A549 cells of wogonin in combination with cisplatin. The anti-tumor effect of wogonin is reported as enhancing cisplatin-induced cell death through activating apoptosis, cleavage of the caspase- 3 substrate PARP, caspase- 3 and ROS production. Zhao et al. [66] assessed the inhibitory effect of wogonin in A549 cells by targeting the inflammatory microenvironment. The results demonstrated inhibition in human monocytic leukemia cell line (THP-1 CM)-induced migration of A549 cells, IL-6-induced EMT, vimentin, N-cadherin, Twist and Snail, and activation of E-cadherin. The inactivation of signal transducer and activation of the transcription 3 (STAT3) signaling pathway was found to be the mechanisms for this effect.

Wang et al. [67] performed a proliferation inhibition assay on A549 cells. The study reported a significant cell proliferation inhibition rate of 54\% in A549 when treated with wogonin. Wogonin also showed an effect on energy metabolism by reducing lactate dehydrogenase (LDH) activity in A549 cells. In a study performed to assess the effect of wogonin on NSCLC cells and to explore their mechanism of action as an anti-tumor inhibitor, wogonin showed a significant cell viability inhibition rate of $31 \%$ and $34 \%$ in 
A549 and A427 cells, respectively. The mechanism of NSCLC cell inhibition is linked to the activation of apoptosis-inducing enzymes, autophagy and formation of ROS [68]. In the study by Chen et al. [69], the anticancer effects of wogonin in different concentrations on A549 cells are examined through regulating cellular pathways to assess cell viability. Results showed that wogonin inhibits cell viability and induces apoptosis in A549 cells through down-regulating HDAC1 and HDAC2 at mRNA and protein levels, and c-Myc oncogene, Sphase kinase-associated protein 2 (Skp2), F-box and WD repeat domain-containing 7 (Fbw7) and Glycogen synthase kinase 3b (GSK3b) at the protein level. A study of the inhibitory effect of wogonin on cell viability of NSCLC cells, Shi et al. [70] reported cell cycle arrest, senescence and apoptosis-induction in A549 cells by the downregulation of protein serum levels and glucocorticoid-inducible kinase 1 (SGK1). Furthermore, wogonin upregulates cellular levels of apoptotic protease activating factor-1 (APAF1), Bax, p21, promyelocytic leukemia protein (PML), growth arrest and DNA damage-inducible 45A(GADD45A) and yippee-like 3 (YPEL3) in A549 cells, which are the key factors involved in apoptosis, senescence and cell cycle arrest. Therefore, it can be suggested that wogonin has a strong anti-proliferative/viability, anti-inflammatory and apoptotic activities against NSCLC cells through regulation of several cellular signaling pathways as the mechanisms for these activities.

\subsection{Wogonoside}

Studies that have examined the in vitro activities of wogonoside on NSCLC cells are limited. A study by Luo et al. [71] reported the inhibition of A549 cells via inducing apoptosis and cell cycle arrest when treated with wogonoside. Wogonoside treatment upregulates cleaved caspase-3/9 and Bax expression, downregulates Bcl-2 expression, and promotes the levels of mitochondrial cytochrome $c$ in the cytosol of A549 cells. Furthermore, wogonoside induces apoptosis and cell cycle arrest by reducing phospho-mTOR and its downstream target p70S6K and increasing phospho-AMPK in A549 cells, suggesting that the AMPK/mTOR signaling pathway may be involved in the apoptotic activity of wogonoside. A study by Wang et al. [72] did not show any anti-proliferative effects of wogonoside on six cancer cell lines, including NSCLC (DMEM). However, the study observed the anti-proliferative activity on DMEM treated with wogonin (the deglycosylation of wogonoside).

\subsection{Oroxylin A}

A few in vitro studies have revealed that oroxylin $\mathrm{A}(\mathrm{OA})$ possesses strong anti-lung cancer activity in NSCLC cell lines. Shen et al. [73] studied the anti-inflammatory effect of $\mathrm{OA}$ on $\mathrm{T}_{\text {regs }}$ in the lung cancer environment by using the $\mathrm{H} 460$ cell line. The results of the study showed that OA inhibits $\mathrm{T}_{\text {regs }}$ production in $\mathrm{H} 460$ cells. Treatment with OA causes an inhibitory effect on the $\mathrm{H} 460$ cells cocultured with Jurkat cells by suppressing TGF 3 -activated Smad3, ERK1/2, c-JUN NH2-terminal kinase (JNK) and p38 signaling pathways. OA also significantly inhibits the DNA binding activity of NF- $\mathrm{kB} / \mathrm{p} 65$ in $\mathrm{H} 460$ cells by reducing phospho-Kappa B kinase $\alpha, \beta$ (IKK $\alpha$, IKK $\beta)$. A study by Wei et al. [74] has been performed to assess the anti-invasive effect of OA on NSCLC cells and the molecular mechanisms involved. The study reported inhibition in A549 and 95-D cell migration/invasion with a $70 \%$ and $73 \%$ inhibition rate OA, respectively. The mechanism of inhibition is attributed to the suppression of Snail/TGF $\beta$-induced EMT through ERK/Glycogen synthase kinase-3 $\beta$ (GSK-3 $\beta$ ) signaling pathway blocking. As a result, OA downregulates expression of CD44v6, MMP-9, and vimentin and upregulates the expression of E-cadherin, and this could lead to the suppression of invasion and migration in Snail-expressing NSCLC cells. Another study by Wei et al. [75] reported the effect of OA on anoikis (cell death)-sensitization and glycolysis-inhibition in NSCLC cells. Results showed that OA suppresses the growth of detached A549 cells and induces anoikis through Src/PI3K/AKT signal pathway inhibition at the Tyr418 and ser316 sites. The study also showed that OA induces anoikis in A549 cells by lowering ATP synthesis, the level of 
glycolysis, lactic acid production and hexokinase II (HK II) glycolytic enzyme activity in mitochondria. A study by Liu et al. [76] was conducted to evaluate the effect of OA with cisplatin on suppression of NSCLC cells under hypoxic conditions. Flow cytometric and CCK8 assays reported that OA promotes cisplatin-induced cell death in H460 cells under hypoxia through inhibiting xeroderma pigmentosum group C (XPC), a DNA damage recognition protein upregulated by HIF- $1 \alpha$, which is implicated in the activation of nucleotide excision repair (NER). It is, therefore, suggested that OA has significant anti-invasive and anti-inflammatory activities in nicotine-induced NSCLC cells, due to their ability to inhibit cellular signaling pathways involved in NSCLC development. The in vitro studies on the anti-NSCLC activity of S. baicalensis/S. radix and their compounds, as well as their molecular mechanisms of action are summarized in Table 2. Taken together, S. baicalensis compounds possess anti-proliferative/metastatic/invasive, anti-inflammatory, anti-angiogenesis and apoptotic/autophagic properties (Figure 1). These compounds showed significant inhibition of NSCLC cells by suppressing/modulating the activity of cellular signaling pathways.

Table 2. Anti-lung cancer activity of S. baicalensis and their flavone compounds in nicotine-induced NSCLC.

\begin{tabular}{|c|c|c|c|c|c|}
\hline S. baicalensis/S. radix/Flavones & Concentration & $\begin{array}{l}\text { NSCLC Cell } \\
\text { Lines Target }\end{array}$ & Activity & $\begin{array}{c}\text { Molecular Mechanism } \\
\text { Target }\end{array}$ & Reference \\
\hline S. baicalensis & $250,500 \mu \mathrm{g} / \mathrm{mL}$ & A549 & $\begin{array}{l}\text { Inhibition of cell } \\
\text { motility/proliferation, } \\
\text { induction of G1 phase } \\
\text { arrest }\end{array}$ & $\begin{array}{c}\text { cyclinD1, CDK4, MMP2 } \\
\downarrow\end{array}$ & [51] \\
\hline S. radix & $750 \mu \mathrm{g} / \mathrm{mL}$ & H2087, Н358 & $\begin{array}{l}\text { Induction of apoptosis } \\
\text { and autophagy }\end{array}$ & $\begin{array}{c}\text { caspase 3, PARP, } \\
\text { LC3-II/LC3-I, AMPK } \uparrow \\
\text { mTOR } \downarrow\end{array}$ & [52] \\
\hline S. radix/baicalein/wogonin & $42.3 \mu \mathrm{g} / \mathrm{mL}$ & A549 & $\begin{array}{l}\text { Inhibition of cell } \\
\text { proliferation/invasion, } \\
\text { induction of } S \text { phase } \\
\text { arrest }\end{array}$ & cyclinD1 $\downarrow, \mathrm{P} 53 \uparrow$ & [53] \\
\hline $\begin{array}{l}\text { S. baicalensis/baicalein/baicalin/ } \\
\text { wogonin }\end{array}$ & $\begin{array}{r}29.8,27.5 \\
16.7 \mu \mathrm{g} / \mathrm{mL}\end{array}$ & $\begin{array}{l}\text { SK-LU-1, A549, } \\
\text { SK-MES-1 }\end{array}$ & $\begin{array}{l}\text { Induction of apoptosis } \\
\text { and } S \text { phase arrest }\end{array}$ & $\begin{array}{l}\text { Bax, P53 } \uparrow \\
\text { cyclinA } \downarrow\end{array}$ & {$[54]$} \\
\hline $\begin{array}{l}\text { S. baicalensis/baicalein/baicalin/ } \\
\text { wogonin }\end{array}$ & $1,10,50 \mu \mathrm{M}$ & A549, H1299 & $\begin{array}{c}\text { Anti-metastatic, } \\
\text { anti-inflammatory, } \\
\text { induction of apoptosis }\end{array}$ & $\begin{array}{c}\text { Bax } \uparrow \\
\text { MMP2,MMP9, } \\
\text { caspase-3, bcl-2/bax, } \\
\text { bcl-2, NF-kB p65, TNF- } \alpha, \\
\text { IL-6, IкB- } \alpha \downarrow\end{array}$ & [55] \\
\hline $\begin{array}{l}\text { S. baicalensis/baicalein/baicalin/ } \\
\text { wogonin }\end{array}$ & $10,40,200 \mu \mathrm{M}$ & A549, H1299 & $\begin{array}{c}\text { Inhibition of cell } \\
\text { migration/invasion, Id1 } \\
\text { inhibition, } \\
\text { anti-angiogenesis }\end{array}$ & $\begin{array}{c}\text { VEGF-A, N-cadherin, } \\
\text { vimentin, a7nAChR, } \\
\text { Akt/Src } \downarrow \\
\text { E-cadherin } \uparrow\end{array}$ & {$[41]$} \\
\hline Baicalein & $40 \mu \mathrm{mol} / \mathrm{L}$ & A549, H460 & $\begin{array}{l}\text { Inhibition of cell } \\
\text { proliferation, induction of } \\
\text { apoptosis }\end{array}$ & PI3K/Akt, miR-424-3p $\downarrow$ & [56] \\
\hline Baicalein & $40 \mu \mathrm{mol} / \mathrm{L}$ & A549 & $\begin{array}{l}\text { Inhibition of cell } \\
\text { motility/viability, } \\
\text { anti-angiogenesis }\end{array}$ & $\begin{array}{c}\text { PI3K, MMP2, MMP9 } \\
\text { MMP14, VE-cadherin, } \\
\text { RhoA/ROCK } \downarrow\end{array}$ & [57] \\
\hline Baicalein & $100,200 \mu \mathrm{M}$ & A549, H1299 & Induction of autophagy & MAP4K3, mTOR $\downarrow$ & {$[58]$} \\
\hline Baicalein & $10,40 \mu \mathrm{mol} / \mathrm{L}$ & A549, H1299 & $\begin{array}{l}\text { Inhibition of cell } \\
\text { invasion/metastasis }\end{array}$ & $\begin{array}{c}\text { ezrin tension } \\
\text { transduction, leader } \\
\text { cells production, iNOS } \downarrow\end{array}$ & {$[59]$} \\
\hline Baicalein & $1,10,100 \mu \mathrm{M}$ & $\begin{array}{l}\text { A549, H460, } \\
\text { SKMES1 }\end{array}$ & Anti-angiogenesis & VEGF-A, FGFR-2, RB- $1 \downarrow$ & [42] \\
\hline Baicalein & $80 \mu \mathrm{mol} / \mathrm{L}$ & A549, H1299 & $\begin{array}{c}\text { Inhibition of cell } \\
\text { proliferation/invasion, } \\
\text { Notch1 } \\
\text { and hes-1 expression }\end{array}$ & $\begin{array}{c}\text { cyclinD1, CDK1, } \\
\text { N-cadherin, vimentin } \downarrow \\
\text { E-cadherin } \uparrow\end{array}$ & {$[60]$} \\
\hline
\end{tabular}


Table 2. Cont.

\begin{tabular}{|c|c|c|c|c|c|}
\hline S. baicalensis/S. radix/Flavones & Concentration & $\begin{array}{l}\text { NSCLC Cell } \\
\text { Lines Target }\end{array}$ & Activity & $\begin{array}{c}\text { Molecular Mechanism } \\
\text { Target }\end{array}$ & Reference \\
\hline Baicalein & $10 \mu \mathrm{M}$ & A549 & Anti-proliferative & $\begin{array}{c}\text { N-cadherin, vimentin, } \\
\text { Src/Id } 1 \downarrow \\
\text { E-cadherin } \uparrow\end{array}$ & [43] \\
\hline Baicalin & $100 \mu \mathrm{M}$ & A549, H2009 & TRAIL-induced apoptosis & MAPK, ROS $\uparrow$ & {$[61]$} \\
\hline Baicalin & $2,4,8 \mu \mathrm{g} / \mathrm{mL}$ & A549/DDP & $\begin{array}{c}\text { Inhibition of cell } \\
\text { proliferation/invasion }\end{array}$ & MARK2 mRNA, p-Akt $\downarrow$ & [62] \\
\hline Baicalin & $25,50,100 \mu \mathrm{M}$ & $\begin{array}{l}\text { H441, H1975, } \\
\text { H1299 }\end{array}$ & $\begin{array}{c}\text { Inhibition of cell } \\
\text { proliferation/invasion }\end{array}$ & PBK $/ \mathrm{TOPK} \downarrow$ & [63] \\
\hline Baicalin & $\begin{array}{c}20,40 \\
80 \mu \mathrm{mol} / \mathrm{L}\end{array}$ & A549, H1299 & $\begin{array}{l}\text { Inhibition of cell } \\
\text { proliferation/invasion } \\
\text { induction of apoptosis }\end{array}$ & $\begin{array}{l}\text { SIRT1/AMPK } \uparrow \\
\text { MMP2, MMP9 } \downarrow\end{array}$ & [64] \\
\hline Wogonin & $20 \mu \mathrm{M}$ & A549 & $\begin{array}{l}\text { Induction of apoptosis, } \\
\text { cisplatin-induced cell } \\
\text { death }\end{array}$ & caspase 3, PARP, ROS $\uparrow$ & [65] \\
\hline Wogonin & $20 \mu \mathrm{M}$ & A549 & $\begin{array}{l}\text { Inhibition of cell } \\
\text { migration/metastasis, } \\
\text { anti-inflammatory }\end{array}$ & $\begin{array}{c}\text { (IL-6)-induced EMT, } \\
\text { N-cadherin, vimentin, } \\
\text { Snail, Twist, STAT3 } \downarrow \\
\text { E-cadherin } \uparrow\end{array}$ & [66] \\
\hline Wogonin & $15 \mu \mathrm{g} / \mathrm{mL}$ & A549 & $\begin{array}{c}\text { Inhibition of cell } \\
\text { proliferation, glucose } \\
\text { metabolism alteration } \\
\end{array}$ & LDH, ATP synthesis $\downarrow$ & [67] \\
\hline Wogonin & $50 \mu \mathrm{M}$ & A549, A427 & $\begin{array}{l}\text { Induction of apoptosis } \\
\text { and autophagy }\end{array}$ & $\begin{array}{c}\text { caspases } 8 / 9 / 3, \text { ROS, } \\
\text { LC3II } \uparrow\end{array}$ & [68] \\
\hline Wogonin & $35 \mu \mathrm{g} / \mathrm{mL}$ & A549 & $\begin{array}{l}\text { Inhibition of cell viability, } \\
\text { induction of apoptosis }\end{array}$ & $\begin{array}{c}\text { HDAC1/2, Skp2, Fbw7, } \\
\text { GSK3b } \downarrow\end{array}$ & [69] \\
\hline Wogonin & $10 \mu \mathrm{M}$ & A549 & $\begin{array}{c}\text { Cell cycle arrest, } \\
\text { senescence, apoptosis }\end{array}$ & $\begin{array}{c}\text { APAF1, Bax, p21, PML, } \\
\text { GADD45A, YPEL3 } \uparrow \\
\text { SGK1 } \downarrow\end{array}$ & [70] \\
\hline Wogonoside & $80 \mu \mathrm{M}$ & A549 & $\begin{array}{l}\text { Induction of apoptosis, } \\
\text { cell cycle arrest }\end{array}$ & $\begin{array}{c}\text { caspases } 3 / 9, \mathrm{Bax}, \\
\text { mitochondrial } \\
\text { cytochrome c, AMPK } \uparrow \\
\text { Bcl-2, mTOR } \downarrow\end{array}$ & {$[71]$} \\
\hline Wogonin & $60,100,200 \mu \mathrm{M}$ & DMEM & Anti-proliferative & caspases 3/9 & [72] \\
\hline Oroxylin A & $40 \mu \mathrm{M}$ & $\mathrm{H} 460$ & Anti-inflammatory & $\begin{array}{c}\mathrm{T}_{\text {regs, }} \text { TGF } \beta, \text { Smad3, } \\
\text { ERK1/2, JNK, P38, } \\
\text { NF-kB } / \mathrm{p} 65, \mathrm{IKK} \alpha, \\
\mathrm{IKK} \beta \downarrow\end{array}$ & [73] \\
\hline Oroxylin A & $16 \mu \mathrm{M}$ & A549,95-D & Anti-invasive/migration & $\begin{array}{c}\text { Snail, ERK/GSK-3 } \beta \text {, } \\
\text { CD44v6, MMP-9, } \\
\text { vimentin } \downarrow \\
\text { E-cadherin } \uparrow\end{array}$ & [74] \\
\hline Oroxylin A & $120 \mu \mathrm{M}$ & A549 & $\begin{array}{l}\text { Anti-invasion, glucose } \\
\text { metabolism alteration }\end{array}$ & $\begin{array}{c}\text { Src/PI3K/AKT, ATP } \\
\text { synthesis, lactic acid } \\
\text { formation, HK II } \downarrow\end{array}$ & [75] \\
\hline Oroxylin A & $50 \mu \mathrm{mol} / \mathrm{L}$ & $\mathrm{H} 460$ & Suppression of XPC & HIF- $1 \alpha \downarrow$ & [76] \\
\hline
\end{tabular}

$(\downarrow)$ decrease, ( $\uparrow$ ) increase. 


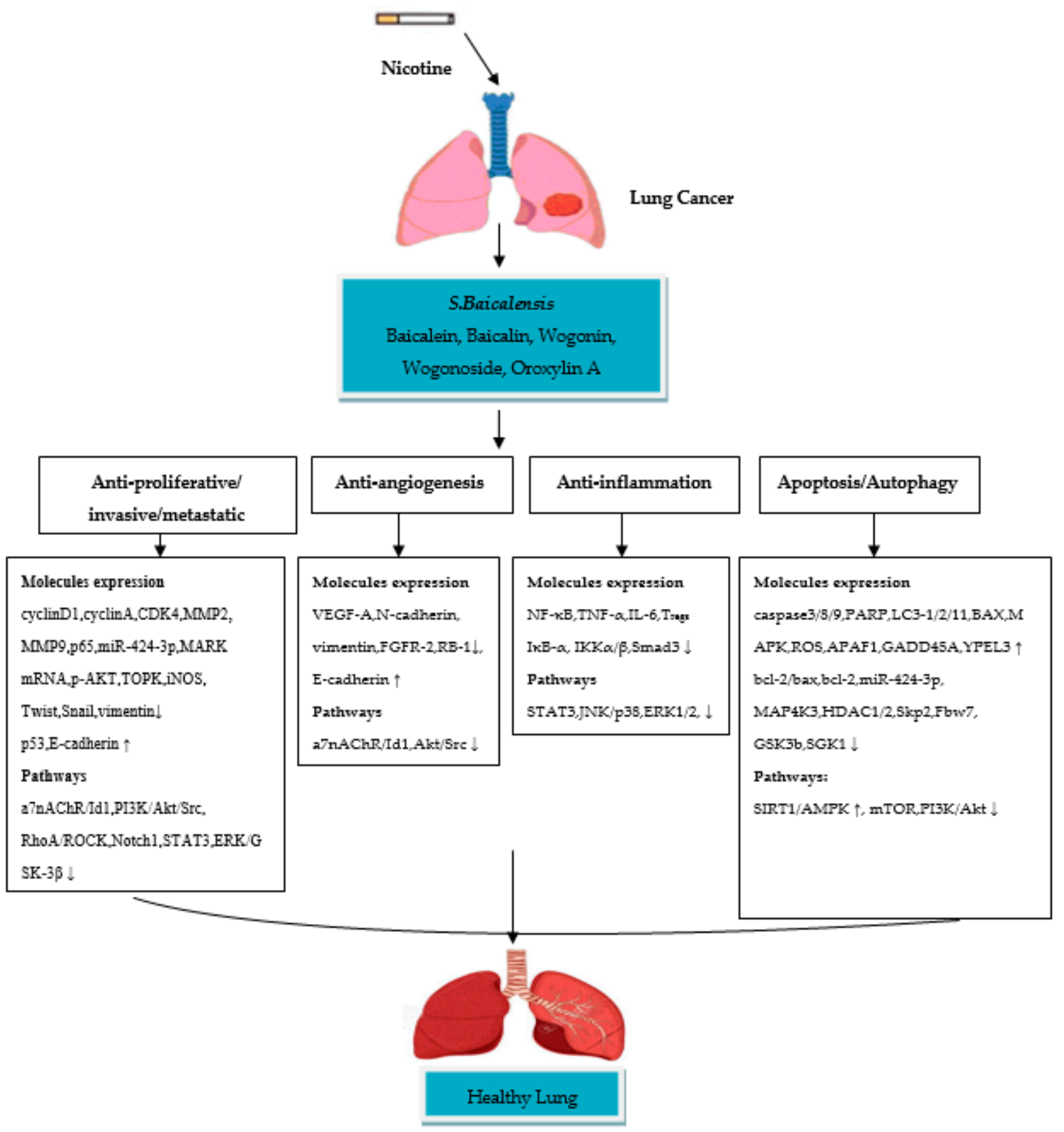

Figure 1. Schematic diagram of the molecular mechanisms of S. baicalensis compounds in nicotine-induced NSCLC treatment. $(\downarrow)$ decrease, $(\uparrow)$ increase.

\section{In Vitro Effects of Nicotine on Asthma Development}

Nicotine has been shown to activate the $\alpha 7 \mathrm{nAChR}$ signaling pathway in lung fibroblasts to induce $\mathrm{NFKB}$ transcriptional activity/nuclear translocation and produce nerve growth factor (NGF) in smokers, which contributes to airway hyperresponsiveness [77]. Nicotine induces upregulation of human bronchial smooth muscle cells (HBSMCs) proliferation by increasing receptor-operated $\mathrm{Ca}^{2+}$ entry (ROCE), store-operated $\mathrm{Ca}^{2+}$ entry (SOCE) and basal $\left[\mathrm{Ca}^{2+}\right]_{i}$ concentrations in these cells, which results through activation of the $\alpha 7 \mathrm{nAChR}$-mediated PI3K/Akt signaling pathway and upregulation of transient receptor potential protein 6 (TRPC6) mRNA and protein expression in HBSMCs [78]. The nicotine component of CSE contributes to asthma by promoting $\left[\mathrm{Ca}^{2+}\right]_{I}$ responses of human airway smooth muscle (hASM) cells to agonist and SOCE through upregulation expression 
of Orai1, CD38, stromal interaction molecule 1 (STIM1) and TRPC3 in hASM cells, which are the key molecular players for activation of sarcoplasmic reticulum $\mathrm{Ca}^{2+}$ release from ryanodine receptor channels [79].

Nicotine promotes the release of pro-inflammatory cytokines such as IL-17A, IL-6 and IL-8 in the bronchial mucosa of asthmatic smokers [80]. IL-17A has the ability to stimulate TGF- $\beta 1$, which contributes to abnormal epithelial barrier function, hASM contraction and airway smooth muscle remodeling in asthma and correlates with promoted TH17 activity in secreting proinflammatory cytokines through NF-kB, PI3K and MAPK signaling pathways activation [81]. IL-17A plays a key pathogenic role in asthma, as it induces some of the growth-related oncogene (GRO) chemokine production (e.g., CXCL2 and CXCL3) [82], which enhance asthmatic airway smooth muscle cell (ASMC) migration by inducing ERK1/2 and p38 MAPK signaling pathways activation via CXCR1 and CXCR2 chemokine receptors [83]. IL-17A and IL4 have a potential synergistic effect with TGF- $\beta 1$ in inducing bronchial EMT, p-Smad3 expression and ERK1/2 signaling pathway activation, and inhibiting E-cadherin mRNA expression in the setting of severe asthma [84]. Research evidence points to an increased IL-4, Th17 and the levels of serum mTOR as playing a key role in asthma development. The mTOR pathway activation in asthmatic patients is demonstrated by Th1/Th2 imbalance and loss of Th17/ $\mathrm{T}_{\text {reg }}$ [85]. Activation of the ROS/PI3K/Akt/mTOR pathway by CSE plays a key role in cell senescence in asthma [86,87] and may contribute to lung inflammation and alterations in asthma [88].

Nicotine has been shown to induce EMT via Wnt/ $\beta$-catenin activation in hASM cells. This process is accompanied by an increase in MMP9, type I collagen and vimentin expression, as well as inhibition of E-cadherin [89]. Nicotine upregulates cyclinD1 expression in HBSMCs in smokers with asthma [90] and also promotes hASM proliferation by increasing the expression of two proliferative markers, known as cyclinE and proliferating cell nuclear antigen (PCNA) [79]. Airway epithelial cell dysfunction in asthma induces EMT through TGF- $\beta$ signaling via noncanonical pathways (e.g., Wnt/ $\beta$-catenin, JNK, Ras small GTPases, PI3K/Akt, p38) and canonical/Smad-dependent pathways (e.g., c-Jun/junB) activation [91]. Nicotine stimulates TGF $\beta 1$-induced EMT in hASM cells [89]. TGF $\beta 1$ stimulation causes a decrease in E-cadherin and an increase in MMPs, snail, twist, fibronectin, $\alpha$-smooth muscle actin ( $\alpha$-SMA) and collagen 1 expression in airway epithelial cells [91]. TGF $\beta$ is increased by the existence of proinflammatory TNF- $\alpha / \mathrm{IL}-1$, which triggers the innate immune response in asthmatics through noncanonical and NF- $\mathrm{KB}$ signaling pathway activation [91]. It has been recently reported that miR-206 down-regulation mediates TGF- $\beta 1$-induced cyclinD1 and HDAC4 up-regulation via activation of $\operatorname{Smad} 2 / 3$, resulting in significantly triggered hASM cell proliferation. However, activation of AMPK suppresses TGF- $\beta 1$-induced hASM cell proliferation and miR-206 inhibition by downregulating HDAC4 and consequently decreased cyclinD1 [92]. It is well recognized that HIF-1 $\alpha$-induced EMT upregulates in bronchial epithelial cells [93]. Expression of HIF-1 $\alpha$ and VEGF in hASM cells is upregulated in asthmatics compared to non-asthmatic patients [94], and that NF- $\kappa B$ signaling may be involved in IL-1 $\beta$-induced HIF- $1 \alpha$ activation through the canonical pathway of NF- $\mathrm{B}$ [95].

CSE stimulates p120-mediated NF- $\mathrm{BB}$ activation in airway epithelial inflammation, which is dependent on the RhoA/ROCK signaling pathway [96]. Activation of the RhoA/ROCK signaling pathway increases airway inflammation in asthmatic patients. Upon activation by G protein-coupled receptor (GPCR) agonist, guanine nucleotide exchange factors (GEFs) enhance the active state by converting GDP-RhoA to GTP-RhoA. GTP-RhoA binds to Rho-kinase and causes contraction of airway smooth muscle. TNF- $\alpha$, IL-13, IL-4, IL-17A and CCL2 are found to increase RhoA mRNA expression via NF- $\kappa \beta$ and STAT6 signaling pathways activation, leading to airway hyperreactivity in asthma. Activation of TGF- $\beta 1$ also has a key role in hASM contraction by increasing RhoA/ROCKmedicated phosphorylation of myosin phosphatase targeting subunit 1 (MYPT1) and myosin light chain (MLC) through PI3K signaling pathway activation [97].

Exposure to the nicotine component of CSE increases the expression of cleaved-caspase (C-caspase-3), cleaved-PARP (C-PARP) and Bax in human bronchial epithelial cells [98]. 
In bronchial mucous cells, the expression level of BAX mRNA was reduced in asthmatic non-smokers compared to non-asthmatics [99]. CSE induces PARP activation and DNA damage in hASM cells but did not induce apoptosis, cleave PARP or caspase 3 [100]. PARP activation may influence the pro-inflammatory cytokine/chemokine production in asthma, which is dependent on NF-KB signaling pathway activation [101]. Furthermore, CSE induces apoptosis in asthmatics in response to apoptosis-inducing factor, which has a key role in ROS-mediated cell-death and DNA damage [102].

Increasing iNOS and arginase I expression in airway epithelial cells of asthmatic patients after nicotine stimulation can result in nitric oxide (NO) production [103], which contributes to the pathological condition to increase the oxidative stress pathway and stimulate T-lymphocytes and eosinophil chemotaxis to the lung, leading to airway remodeling and inflammation [104].

Taken together, nicotine may contribute significantly to asthma by inducing cell proliferation, angiogenesis, inflammation and apoptosis of hASM/HBSMCs. These effects may occur via activation of signaling pathways mediated through the $\alpha 7 \mathrm{nAChR}$, including the PI3K/Akt and ERK/MAPK, as well as through canonical/Smad-dependent and noncanonical signaling pathway activation.

\section{Therapeutic Role of Scutellaria baicalensis and Their Flavone Compounds in Nicotine-Induced Asthma}

Few in vitro studies so far have tested the anti-allergic activity of flavone compounds in S. baicalensis. Some of these compounds are proven to be effective when tested on normal/allergic bronchial airway epithelial cells. However, it is still unknown how these compounds exert their therapeutic effects in nicotine-induced asthmatic bronchial airway epithelial cells. A study of normal bronchial epithelial (BEAS-2B) cells indicates that baicalein inhibits TNF- $\alpha$-induced $\mathrm{p}-\mathrm{I} \kappa \mathrm{B} \alpha$ protein levels at a concentration of $2.5 \mu \mathrm{M} / \mathrm{mL}$ through inhibiting the NF-kB p65 signaling pathway [105]. In a study conducted by Dong et al. [106], human airway epithelial cells HBE16 were treated with $10 \mu \mathrm{g} / \mathrm{mL}$ lipopolysaccharide (LPS) to study the anti-inflammatory effect of baicalin on LPS-induced HBE16 cells. The results showed that baicalin inhibits $\mathrm{p}-\mathrm{IKK} \alpha / \beta$ and activates $\mathrm{I} \kappa \mathrm{B} \alpha$ to suppress the LPS-induced NF- $k B$ signaling pathway activation via binding TLRs, leading to inhibited TNF- $\alpha$, IL-8 and IL-6 expression at the mRNA level.

The efficacy of flavone compounds in S. baicalensis to treat asthma is not yet confirmed. Thus, understanding conditions associated with bronchial airway wall remodeling in asthma might provide an opportunity to explore the therapeutic potential of flavone compounds in asthma. It is well known that bronchial fibroblasts and myofibroblasts are implicated in subepithelial fibrosis, a characteristic feature of bronchial airway remodeling in asthma [107]. In allergic asthma, the subepithelial fibrosis in lamina reticularis is caused by exaggerated deposition of extracellular matrix (ECM) protein components (e.g., fibronectin and collagen I, III and V) and $\alpha$-SMA, which are activated by myofibroblasts [108]. Phenotypic fibroblast to myofibroblast transition in asthma is a process characterized by an increased number of myofibroblasts in fibrotic lung tissue as a result of EMT, and activated by several factors, including TGF- $\beta$, interleukins (e.g., TNF- $\alpha$, IL-4, IL-5, IL-11, IL-13) and chemokines (e.g., periostin, osteopontin, eotaxin), which contribute to bronchial remodeling [108]. Asthmatic bronchial fibroblasts have been shown to be involved in NSCLC cell development. A previous study indicates that bronchial fibroblasts derived from asthmatic patients activate the colonization of lung tumors by increasing A549 cell motility and upregulating Snail-1/connexin43 (Cx43) expression in A549 cells [109].

Idiopathic pulmonary fibrosis (IPF) is considered a contributing factor to lung cancer, which shares characteristics with asthma such as inflammation and fibroblast proliferation that may link both diseases to the development of NSCLC. IPF, a chronic and progressive subtype of fibrosing interstitial lung disease (ILD) [110], increases the risk of NSCLC development and in smoking-related subtype SCC in particular [111,112], as a result of aberrant fibroblast proliferation, myofibroblast activation, oxidative stress, growth factor expression alterations and myofibroblast/mesenchymal transition [112]. In IPF lungs, it 
has been shown that TGF- $\beta$, VEGF, FGF, cytokines and chemokines (e.g., IL-13, CCL2), ROS, Wnt/ $\beta$-catenin pathway, PI3K/AKT/mTOR pathway, Notch signaling pathway, ECM protein components, pulmonary arterial endothelial cell to mesenchymal transition (EnMT) and $\alpha$-SMA are hypothesized as potential sources/mechanisms of myofibroblast activation, which contribute to lung fibrosis and lead to aberrant fibroblast proliferation and apoptosis of NSCLC cells [112]. Given these findings, this review hypothesizes that asthmatic bronchial airway epithelial cells may display a similar characteristic profile in cell surface markers with NSCLC cells, where studies are needed to further investigate possible mechanisms. Flavone compounds in S. baicalensis efficacy were confirmed by in vitro studies to exert a protective effect against nicotine-induced NSCLC, which may be due to the presence of C-6 and C-8 hydroxyl/methoxy groups in these flavones at the Aring [39]. Therefore, this prompts us to hypothesize that these compounds may be involved in nicotine-induced asthma treatment. Table 3 shows the potential therapeutic activity of flavone compounds in nicotine-induced asthma. Future directions for exploring possible mechanisms underlying the therapeutic effects of these compounds in nicotine-induced asthma are warranted.

Table 3. Therapeutic potential of flavone compounds from S. baicalensis in nicotine-induced asthma.

\begin{tabular}{|c|c|}
\hline Activity & Mechanism of Action \\
\hline Anti-inflammatory & $\begin{array}{l}\text { Downregulate expression of pro-inflammatory cytokines (IL-4, IL-6, IL-8, IL-17A, TNF- } \alpha / \text { IL-1) and } \\
\text { chemokines (CXCR1, CXCR2) in hASM cells through inhibiting TGF- } \beta 1 \text {-induced EMT, p-Smad3, ERK1/2 } \\
\text { and p38 MAPK, and noncanonical and NF-KB signaling pathways } \\
\text { Suppress expression of TNF- } \alpha \text {, IL-13, IL-4, IL-17A and CCL2 via inhibiting NF-kB, STAT6, PI3K and } \\
\text { RhoA/ROCK signaling pathways activation, which may lead to downregulation of RhoA mRNA expression }\end{array}$ \\
\hline Anti-proliferation & $\begin{array}{c}\text { Inhibit } \alpha 7 n \text { AChR-mediated PI3K/Akt signaling pathway activation and downregulate TRPC6 mRNA and } \\
\text { protein expression, which may lead to decreased ROCE, SOCE and basal }\left[\mathrm{Ca}^{2+}\right]_{\mathrm{i}} \text { levels in HBSMCs } \\
\text { Suppress Orai1, CD38, STIM1 expression and TRPC3-mediated SOCE in hASM cells } \\
\text { Downregulate TGF- } \beta 1 \text {-induced cyclinD1, cyclinE, PCNA and HDAC4 and up-regulate miR-206 expression } \\
\text { through inhibiting Smad2/3 signaling pathway activation }\end{array}$ \\
\hline Anti-angiogenesis & $\begin{array}{l}\text { Downregulate expression of VEGF and IL- } 1 \beta \text {-induced HIF- } 1 \alpha \text { activation in hASM cells via suppressing } \\
\text { NF- } \mathrm{B} \text { signaling pathway } \\
\text { Suppress MMPs, snail, twist and fibronectin, and up-regulate E-cadherin expression through noncanonical } \\
\text { signaling pathway inactivation }\end{array}$ \\
\hline Anti-apoptosis & $\begin{array}{l}\text { Inhibit NF- } \mathrm{kB} \text { signaling pathway activation and ROS production, which may lead to decreased PARP and } \\
\text { BAX expression in hASM/HBSMCs }\end{array}$ \\
\hline
\end{tabular}

\section{Conclusions}

S. baicalensis and its flavone compounds exert therapeutic effects in nicotine-induced NSCLC. The therapeutic effect of $S$. baicalensis and its compounds against NSCLC cells induced by nicotine as an activator of $\alpha 7 \mathrm{nAChR}$ are attributed to its ability to inhibit proliferation, invasion, migration, metastasis and angiogenesis, as well as inducing apoptosis, cell cycle arrest and autophagy via inhibiting signaling pathways involved in NSCLC development. Thus, inhibition of $\alpha 7 \mathrm{nAChR}$ and its downstream signaling pathways by flavones compounds could be a potential target for drug development of nicotine-induced NSCLC cells and NSCLC treatment in smokers. The combination of flavone compounds with chemotherapeutic agents such as cisplatin that could modulate NSCLC-related signaling pathways is a potential strategy to increase the agent anti-NSCLC activity. Therefore, flavones compounds alone or in combination with chemotherapeutics could be approved anti-NSCLC medicinal drugs in smokers.

The mechanisms by which flavone compounds in S. baicalensis exhibit anti-asthma activity for use as medicinal drugs in nicotine-induced asthma remain unclear. Nicotine may contribute to asthma by inducing cell proliferation, angiogenesis, inflammation and apoptosis of hASM/HBSMCs through activation of cellular signaling pathways. Flavone compounds in S. baicalensis may have therapeutic potential in nicotine-induced asthma. The 
use of these compounds is not part of standard treatment of NSCLC and asthma. Integrative medicine is being part of the treatment of these diseases during last years as clinical trials with promising results. Further mechanistic studies to explore the link between asthmatic bronchial fibroblasts and NSCLC development are needed to ascertain the role of flavone compounds as potentially therapeutic in nicotine-induced asthma. Further studies are also needed to investigate the therapeutic efficacy and safety of S. baicalensis and its compounds for the treatment of smoker patients with NSCLC and asthma.

Funding: This review received no financial support.

Institutional Review Board Statement: Not applicable.

Informed Consent Statement: Not applicable.

Data Availability Statement: Not applicable.

Conflicts of Interest: The author declares no conflict of interest.

\section{References}

1. Bray, F.; Jacques, F.; Soerjomataram, I.; Siegel, R.L.; Torre, L.A.; Jemal, A. Global cancer statistics 2018: GLOBOCAN estimates of incidence and mortality worldwide for 36 cancers in 185 countries. CA Cancer J. Clin. 2018, 68, 394-424. [CrossRef]

2. Dillekås, H.; Rogers, M.S.; Straume, O. Are 90\% of deaths from cancer caused by metastases? Cancer Med. 2019, 8, 5574-5576. [CrossRef]

3. Molina, J.R.; Yang, P.; Cassivi, S.D.; Schild, S.E.; Adjei, A.A. Non-small cell lung cancer: Epidemiology, risk factors, treatment, and survivorship. Mayo Clin. Proc. 2008, 83, 584-594. [CrossRef]

4. Institute for Health Metrics and Evaluation. Global Burden of Disease. 2017. Available online: http://vizhub.healthdata.org/ gbd-compare/\# (accessed on 2 February 2020).

5. Sanner, T.; Grimsrud, T.K. Nicotine: Carcinogenicity and effects on response to cancer treatment-A review. Front. Oncol. 2015, 5, 196. [CrossRef] [PubMed]

6. Hecht, S.S. Lung carcinogenesis by tobacco smoke. Int. J. Cancer 2012, 131, 2724-2732. [CrossRef] [PubMed]

7. Warren, G.W.; Singh, A.K. Nicotine and lung cancer. J. Carcinog. 2013, 12, 1. [CrossRef]

8. Nagathihalli, N.S.; Massion, P.P.; Gonzalez, A.L.; Lu, P.; Datta, P.K. Smoking induces epithelial-to-mesenchymal transition in non-small cell lung cancer through HDAC-mediated downregulation of E-cadherin. Mol. Cancer Ther. 2012, 11, $2362-2372$. [CrossRef]

9. Vu, T.; Jin, L.; Datta, P.K. Effect of cigarette smoking on epithelial to mesenchymal transition (EMT) in lung cancer. J. Clin. Med. 2016, 5, 44. [CrossRef] [PubMed]

10. Zahedi, A.; Phandthong, R.; Chaili, A.; Lemark, G.; Talbot, P. Epithelial-to-mesenchymal transition of A549 lung cancer cells exposed to electronic cigarettes. Lung Cancer 2018, 122, 224-233. [CrossRef] [PubMed]

11. Sui, H.; Ma, N.; Wang, Y.; Li, H.; Liu, X.; Su, Y.; Yang, J. Anti-PD-1/PD-L1 therapy for non-small-cell lung cancer: Toward personalized medicine and combination strategies. J. Immunol. Res. 2018, 2018, 6984948. [CrossRef] [PubMed]

12. Neeve, S.C.; Robinson, B.W.; Fear, V.S. The role and therapeutic implications of T cells in cancer of the lung. Clin. Transl. Immunol. 2019, 8, e1076. [CrossRef]

13. Palata, O.; Hradilova, N.P.; Mysiková, D.; Kutna, B.; Mrazkova, H.; Lischke, R.; Spisek, R.; Adkins, I. Detection of tumor antigens and tumor-antigen specific T cells in NSCLC patients: Correlation of the quality of T cell responses with NSCLC subtype. Immunol. Lett. 2020, 219, 46-53. [CrossRef] [PubMed]

14. Doeing, D.C.; Solway, J. Airway smooth muscle in the pathophysiology and treatment of asthma. J. Appl. Physiol. 2013, 114, 834-843. [CrossRef]

15. Skaaby, T.; Taylor, A.E.; Jacobsen, R.K.; Paternoster, L.; Thuesen, B.H.; Ahluwalia, T.S.; Larsen, S.C.; Zhou, A.; Wong, A.; Gabrielsen, M.E.; et al. Investigating the causal effect of smoking on hay fever and asthma: A Mendelian randomization meta-analysis in the CARTA consortium. Sci. Rep. 2017, 7, 2224. [CrossRef] [PubMed]

16. McLeish, A.C.; Cougle, J.R.; Zvolensky, M.J. Asthma and cigarette smoking in a representative sample of adults. J. Health Psychol. 2011, 16, 643-652. [CrossRef]

17. Qu, Y.L.; Liu, J.; Zhang, L.X.; Wu, C.M.; Chu, A.J.; Wen, B.L.; Ma, C.; Yan, X.Y.; Zhang, X.; Wang, D.M.; et al. Asthma and the risk of lung cancer: A meta-analysis. Oncotarget 2017, 8, 48525. [CrossRef]

18. Cheng, B.; Xiong, S.; Li, C.; Liang, H.; Zhao, Y.; Li, J.; Shi, J.; Ou, L.; Chen, Z.; Liang, P.; et al. An annual review of the remarkable advances in lung cancer clinical research in 2019. J. Thorac. Dis. 2020, 12, 1056-1069. [CrossRef] [PubMed]

19. Nasser, N.J.; Gorenberg, M.; Agbarya, A. First line immunotherapy for non-small cell lung cancer. Pharmaceuticals 2020, $13,373$. [CrossRef] 
20. Dafni, U.; Tsourti, Z.; Vervita, K.; Peters, S. Immune checkpoint inhibitors, alone or in combination with chemotherapy, as first-line treatment for advanced non-small cell lung cancer. A systematic review and network meta-analysis. Lung Cancer 2019, 134, 127-140. [CrossRef]

21. Alsharairi, N.A. Supplements for smoking-related lung diseases. Encyclopedia 2021, 1, 76-86. [CrossRef]

22. Alsharairi, N. The effects of dietary supplements on asthma and lung cancer risk in smokers and non-smokers: A review of the literature. Nutrients 2019, 11, 725. [CrossRef]

23. Panche, A.N.; Diwan, A.D.; Chandra, S.R. Flavonoids: An overview. J. Nutr. Sci. 2016, 5, e47. [CrossRef]

24. Kumar, S.; Pandey, A.K. Chemistry and biological activities of flavonoids: An overview. Sci. World J. 2013, 2013, 162750. [CrossRef]

25. Chahar, M.K.; Sharma, N.; Dobhal, M.P.; Joshi, Y.C. Flavonoids: A versatile source of anticancer drugs. Pharm. Rev. 2011, 5, 1-12.

26. Zanoaga, O.; Braicu, C.; Jurj, A.; Rusu, A.; Buiga, R.; Berindan-Neagoe, I. Progress in research on the role of flavonoids in lung cancer. Int. J. Mol. Sci. 2019, 20, 4291. [CrossRef] [PubMed]

27. Masraksa, W.; Tanasawet, S.; Hutamekalin, P.; Wongtawatchai, T.; Sukketsiri, W. Luteolin attenuates migration and invasion of lung cancer cells via suppressing focal adhesion kinase and non-receptor tyrosine kinase signaling pathway. Nutr. Res. Pract. 2020, 14, 127-133. [CrossRef]

28. Weng, Z.; Patel, A.B.; Panagiotidou, S.; Theoharides, T.C. The novel flavone tetramethoxyluteolin is a potent inhibitor of human mast cells. J. Allergy Clin. Immunol. 2015, 135, 1044-1052.e5. [CrossRef]

29. Rouhi-Boroujeni, H.; Heidarian, E.; Rouhi-Boroujeni, H.; Deris, F.; Rafieian-Kopaei, M. Medicinal plants with multiple effects on cardiovascular diseases: A systematic review. Curr. Pharm. Des. 2017, 23, 999-1015. [CrossRef]

30. Sharifi-Rad, M.; Lankatillake, C.; Dias, D.A.; Docea, A.O.; Mahomoodally, M.F.; Lobine, D.; Chazot, P.L.; Kurt, B.; Tumer, T.B.; Moreira, A.C.; et al. Impact of natural compounds on neurodegenerative disorders: From preclinical to pharmacotherapeutics. J. Clin. Med. 2020, 9, 1061. [CrossRef] [PubMed]

31. Li, T.; Zhang, A.; Miao, J.; Sun, H.; Yan, G.; Wu, F.; Wang, X. Applications and potential mechanisms of herbal medicines for rheumatoid arthritis treatment: A systematic review. RSC Adv. 2019, 9, 26381. [CrossRef]

32. Amaral-Machado, L.; Oliveira, W.N.; Moreira-Oliveira, S.S.; Pereira, D.T.; Alencar, E.N.; Tsapis, N.; Egito, E.S.T. Use of natural products in asthma treatment. Evid. Based Complement. Altern. Med. 2020, 2020, 1021258. [CrossRef] [PubMed]

33. De Sousa Monteiro, L.; Bastos, K.X.; Barbosa-Filho, J.M.; de Athayde-Filho, P.F.; Diniz, M.D.; Sobral, M.V. Medicinal plants and other living organisms with antitumor potential against lung cancer. Evid. Based Complement. Altern. Med. 2014, $2014,604152$.

34. Farzaei, M.H.; Bayrami, Z.; Farzaei, F.; Aneva, I.; Das, S.K.; Patra, J.K.; Das, G.; Abdollahi, M. Poisoning by medical plants. Arch. Iran. Med. 2020, 23, 117-127. [PubMed]

35. Mali, R.G.; Dhake, A.S. A review on herbal antiasthmatics. Orient. Pharm. Exp. Med. 2011, 11, 77-90. [CrossRef]

36. Taur, D.J.; Patil, R.Y. Some medicinal plants with antiasthmatic potential: A current status. Asian Pac. J. Trop. Biomed. 2011, 1, 413-418. [CrossRef]

37. Zhao, Q.; Chen, X.; Martin, C. Scutellaria baicalensis, the golden herb from the garden of Chinese medicinal plants. Sci. Bull. 2016, 61, 1391-1398. [CrossRef]

38. Zhao, T.; Tang, H.; Xie, L.; Zheng, Y.; Ma, Z.; Sun, Q.; Li, X. Scutellaria baicalensis Georgi. (Lamiaceae): A review of its traditional uses, botany, phytochemistry, pharmacology and toxicology. J. Pharm. Pharmacol. 2019, 71, 1353-1369. [CrossRef]

39. Wang, Z.; Wang, S.; Kuang, Y.; Hu, Z.; Qiao, X.; Ye, M. A comprehensive review on phytochemistry, pharmacology, and flavonoid biosynthesis of Scutellaria baicalensis. Pharm. Biol. 2018, 56, 465-484. [CrossRef]

40. Khan, T.; Ali, M.; Khan, A.; Nisar, P.; Jan, S.A.; Afridi, S.; Shinwari, Z.H. Anticancer plants: A review of the active phytochemicals, applications in animal models, and regulatory aspects. Biomolecules 2019, 10, 47. [CrossRef] [PubMed]

41. Zhao, Z.; Liu, B.; Sun, J.; Lu, L.; Liu, L.; Qiu, J.; Li, Q.; Yan, C.; Jiang, S.; Mohammadtursun, N.; et al. Scutellaria flavonoids effectively inhibit the malignant phenotypes of non-small cell lung cancer in an Id1-dependent manner. Int. J. Biol. Sci. 2019, 15, 1500-1513. [CrossRef] [PubMed]

42. Cathcart, M.; Useckaite, Z.; Drakeford, C.; Semik, V.; Lysaght, J.; Gately, K.; O’Byrne, K.J.; Pidgeon, G.P. Anti-cancer effects of baicalein in non-small cell lung cancer in-vitro and in-vivo. BMC Cancer 2016, 16, 707. [CrossRef]

43. Zhao, Z.; Liu, B.; Sun, J.; Lu, L.; Liu, L.; Qiu, J.; Li, Q.; Yan, C.; Jiang, S.; Mohammadtursun, N.; et al. Baicalein inhibits orthotopic human non-small cell lung cancer xenografts via Src/Id1 pathway. Evid. Based Complement. Altern. Med. 2019, $2019,9806062$. [CrossRef] [PubMed]

44. Schaal, C.; Chellappan, S.P. Nicotine-mediated cell proliferation and tumor progression in smoking-related cancers. Mol. Cancer Res. 2014, 12, 14-23. [CrossRef]

45. Chernyavsky, A.I.; Shchepotin, I.B.; Galitovkiy, V.; Grando, S.A. Mechanisms of tumor-promoting activities of nicotine in lung cancer: Synergistic effects of cell membrane and mitochondrial nicotinic acetylcholine receptors. BMC Cancer 2015, 15, 152. [CrossRef] [PubMed]

46. Wang, S.; Hu, Y. $\alpha 7$ nicotinic acetylcholine receptors in lung cancer (Review). Oncol. Lett. 2018, 16, 1375-1382. [CrossRef]

47. Yuan, X.; Wu, H.; Han, N.; Xu, H.; Chu, Q.; Yu, S.; Chen, Y.; Wu, K. Notch signaling and EMT in non-small cell lung cancer: Biological significance and therapeutic application. J. Hematol. Oncol. 2014, 7, 87. [CrossRef]

48. Xiao, D.; He, J. Epithelial mesenchymal transition and lung cancer. J. Thorac. Dis. 2010, 2, 154-159.

49. Cheng, W.; Chen, K.; Lee, K.; Feng, P.; Wu, S. Nicotinic-nAChR signaling mediates drug resistance in lung cancer. J. Cancer 2020, 11, 1125-1140. [CrossRef] [PubMed] 
50. Hajiasgharzadeh, K.; Sadigh-Eteghad, S.; Mansoori, B.; Mokhtarzadeh, A.; Shanehbandi, D.; Doustvandi, M.A.; Asadzadeh, Z.; Baradaran, B. Alpha7 nicotinic acetylcholine receptors in lung inflammation and carcinogenesis: Friends or foes? J. Cell Physiol. 2019, 1-14. [CrossRef] [PubMed]

51. Park, K.I.; Park, H.S.; Kang, S.R.; Nagappan, A.; Lee, D.H.; Kim, J.A.; Han, D.Y.; Kim, G.S. Korean Scutellariabaicalensis water extract inhibits cell cycle G1/S transition by suppressing cyclin D1 expression and matrix-metalloproteinase-2 activity in human lung cancer cells. J. Ethnopharmacol. 2011, 133, 634-641. [CrossRef] [PubMed]

52. Kim, H.I.; Hong, S.H.; Ku, J.O.; Lim, Y.S.; Lee, S.J.; Song, J.; Kim, T.Y.; Cheon, C.; Ko, S. Scutellaria radix promotes apoptosis in non-small cell lung cancer cells via induction of AMPK-dependent autophagy. Am. J. Chin. Med. 2019, 47, 691-705. [CrossRef]

53. Wang, Y.; Cao, H.-J.; Sun, S.-J.; Dai, J.-Y.; Fang, J.-W.; Li, Q.-H.; Yan, C.; Mao, W.-W.; Zhang, Y.-Y. Total flavonoid aglycones extract in Radix Scutellariae, inhibits lung carcinoma and lung metastasis by affecting cell cycle and DNA synthesis. J. Ethnopharmacol. 2016, 194, 269-279. [CrossRef]

54. Gao, J.; Morgan, W.A.; Sanchez-Medina, A.; Corcoran, O. The ethanol extract of Scutellariabaicalensis and the active compounds induce cell cycle arrest and apoptosis including upregulation of p53 and Bax in human lung cancer cells. Toxicol. Appl. Pharmacol. 2011, 254, 221-228. [CrossRef]

55. Gong, W.; Wu, J.; Liu, B.; Zhang, H.; Cao, Y.; Sun, J.; Lv, Y.; Wu, X.; Dong, J. Flavonoid components in Scutellariabaicalensis inhibit nicotine-induced proliferation, metastasis and lung cancer-associated inflammation in vitro. Int. J. Oncol. 2014, 44, 1561-1570. [CrossRef] [PubMed]

56. Lu, C.; Wang, H.; Chen, S.; Yang, R.; Li, H.; Zhang, G. Baicalein inhibits cell growth and increases cisplatin sensitivity of A549 and H460 cells via miR-424-3p and targeting PTEN/PI3K/Akt pathway. J. Cell. Mol. Med. 2018, 22, 2478-2487. [CrossRef]

57. Zhang, Z.; Nong, L.; Chen, M.; Gu, X.; Zhao, W.; Liu, M.; Cheng, W. Baicalein suppresses vasculogenic mimicry through inhibiting RhoA/ROCK expression in lung cancer A549 cell line. Acta Biochim. Biophys. Sin. 2020, 52, 1007-1015. [CrossRef]

58. Li, J.; Yan, L.; Luo, J.; Tong, L.; Gao, Y.; Feng, W.; Wang, F.; Cui, W.; Li, S.; Sun, Z. Baicalein suppresses growth of non-small cell lung carcinoma by targeting MAP4K3. Biomed. Pharmacother. 2021, 133, 110965. [CrossRef] [PubMed]

59. Zhang, X.; Ruan, Q.; Zhai, Y.; Lu, D.; Li, C.; Fu, Y.; Zheng, Z.; Song, Y.; Guo, J. Baicalein inhibits non-small-cell lung cancer invasion and metastasis by reducing ezrin tension in inflammation microenvironment. Cancer Sci. 2020, 111, 3802-3812. [CrossRef] [PubMed]

60. Su, G.; Chen, H.; Sun, X. Baicalein suppresses non small cell lung cancer cell proliferation, invasion and Notch signaling pathway. Cancer Biomark. 2018, 22, 13-18. [CrossRef] [PubMed]

61. Zhang, L.; Wang, X.; Wang, R.; Zheng, X.; Li, N.; Li, H.; Cao, X.; Zhou, B.; Lin, Y.; Yang, L. Baicalin potentiates TRAIL-induced apoptosis through p38 MAPK activation and intracellular reactive oxygen species production. Mol. Med. Rep. 2017, 16, 8549-8555. [CrossRef]

62. Xu, Z.; Mei, J.; Tan, Y. Baicalin attenuates DDP (cisplatin) resistance in lung cancer by downregulating MARK2 and p-Akt. Int. J. Oncol. 2017, 50, 93-100. [CrossRef]

63. Diao, X.; Yang, D.; Chen, Y.; Liu, W. Baicalin suppresses lung cancer growth by targeting PDZ-binding kinase/T-LAK celloriginated protein kinase. Biosci. Rep. 2019, 39, BSR20181692. [CrossRef]

64. You, J.; Cheng, J.; Yu, B.; Duan, C.; Peng, J. Baicalin a Chinese herbal medicine, inhibits the proliferation and migration of human non-small cell lung carcinoma (NSCLC) cells, A549 and H1299, by activating the SIRT1/AMPK signaling pathway. Med. Sci. Monit. 2018, 24, 2126-2133. [CrossRef] [PubMed]

65. He, F.; Wang, Q.; Zheng, X.; Yan, J.; Yang, L.; Sun, H.; Hu, L.; Lin, Y.; Wang, X. Wogonin potentiates cisplatin-induced cancer cell apoptosis through accumulation of intracellular reactive oxygen species. Oncol. Rep. 2012, 28, 601-605. [CrossRef] [PubMed]

66. Zhao, Y.; Yao, J.; Wu, X.; Zhao, L.; Zhou, Y.; Zhang, Y.; You, Q.; Guo, Q.; Lu, N. Wogonin suppresses human alveolar adenocarcinoma cell A549 migration in inflammatory microenvironment by modulating the IL-6/STAT3 signaling pathway. Mol. Carcinog. 2015, 1, E81-E93. [CrossRef] [PubMed]

67. Wang, S.; Zhao, J.; Ren, S.; Sun, W.; Zhang, W.; Zhang, J. Wogonin affects proliferation and the energy metabolism of SGC-7901 and A549 cells. Exp. Ther. Med. 2019, 17, 911-918. [CrossRef]

68. Wang, C.; Cui, C. Inhibition of lung cancer proliferation by wogonin is associated with activation of apoptosis and generation of reactive oxygen species. Balk. Med. J. 2019, 37, 29-33. [CrossRef]

69. Chen, X.; Bai, Y.; Zhong, Y.; Xie, X.; Long, H.; Yang, Y.; Wu, S.; Jia, Q.; Wang, X. Wogonin has multiple anti-cancer effects by regulating c-Myc/SKP2/Fbw7 $\alpha$ and HDAC1/HDAC2 pathways and inducing apoptosis in human lung adenocarcinoma cell line A549. PLoS ONE 2013, 8, e79201. [CrossRef] [PubMed]

70. Shi, G.; Wang, Q.; Zhou, X.; Li, J.; Liu, H.; Gu, J.; Wang, H.; Wu, Y.; Ding, L.; Ni, S.; et al. Response of human non-small-cell lung cancer cells to the influence of Wogonin with SGK1 dynamics. Acta Biochim. Biophys. Sin. 2017, 49, 302-310. [CrossRef]

71. Luo, M.; Mo, J.; Yu, Q.; Zhou, S.; Ning, R.; Zhang, Y.; Su, C.; Wang, H.; Cui, J. Wogonoside induces apoptosis in human non-small cell lung cancer A549 cells by promoting mitochondria dysfunction. Biomed. Pharmacother. 2018, 106, 593-598. [CrossRef]

72. Wang, C.; Wan, J.; Zhang, C.; Lu, F.; Chen, L.; Yuan, C. Deglycosylation of wogonoside enhances its anticancer potential. J. Cancer Res. Ther. 2018, 14, S594-S599. [CrossRef]

73. Shen, L.; Zhang, L.; Li, H.; Liu, X.; Yu, X.; Hu, P.; Hui, H.; Guo, Q.; Zhang, S. Oroxylin A inhibits the generation of Tregs in non-small cell lung cancer. Oncotarget 2017, 8, 49395-49408. [CrossRef] 
74. Wei, L.; Yao, Y.; Zhao, K.; Huang, Y.; Zhou, Y.; Zhao, L.; Guo, Q.; Lu, N. Oroxylin A inhibits invasion and migration through suppressing ERK/GSK-3 $\beta$ signaling in snail-expressing non-small-cell lung cancer cells. Mol. Carcinog. 2016, 55, 2121-2134. [CrossRef]

75. Wei, L.; Dai, Q.; Zhou, Y.; Zou, M.; Li, Z.; Lu, N.; Guo, Q. Oroxylin A sensitizes non-small cell lung cancer cells to anoikis via glucose-deprivation-like mechanisms: C-Src and hexokinase II. Biochim. Biophys. Acta 2013, 1830, 3835-3845. [CrossRef]

76. Liu, Y.; Wang, X.; Li, W.; Xu, Y.; Zhuo, Y.; Li, M.; He, Y.; Wang, X.; Guo, Q.; Zhao, L.; et al. Oroxylin A reverses hypoxia-induced cisplatin resistance through inhibiting HIF-1 $\alpha$ mediated XPC transcription. Oncogenesis 2020, 39, 6893-6905. [CrossRef] [PubMed]

77. Wongtrakool, C.; Grooms, K.; Bijli, K.M.; Crothers, K.; Fitzpatrick, A.M.; Hart, C.M. Nicotine stimulates nerve growth factor in lung fibroblasts through an NFKB-dependent mechanism. PLoS ONE 2014, 9, e109602. [CrossRef] [PubMed]

78. Hong, W.; Peng, G.; Hao, B.; Liao, B.; Zhao, Z.; Zhou, Y.; Peng, F.; Ye, X.; Huang, L.; Zheng, M.; et al. Nicotine-induced airway smooth muscle cell proliferation involves TRPC6-dependent calcium influx via $\alpha 7 \mathrm{nAChR}$. Cell. Physiol. Biochem. 2017, 43, 986-1002. [CrossRef]

79. Wylam, M.E.; Sathish, V.; VanOosten, S.K.; Freeman, M.; Burkholder, D.; Thompson, M.A.; Pabelick, C.M.; Prakash, Y.S. Mechanisms of cigarette smoke effects on human airway smooth muscle. PLoS ONE 2015, 10, e0128778. [CrossRef]

80. Siew, L.Q.C.; Wu, S.; Ying, S.; Corrigan, C.J. Cigarette smoking increases bronchial mucosal IL-17A expression in asthmatics, which acts in concert with environmental aeroallergens to engender neutrophilic inflammation. Clin. Exp. Allergy 2017, 47, 740-750. [CrossRef] [PubMed]

81. Evasovic, J.M.; Singer, C.A. Regulation of IL-17A and implications for TGF- $\beta 1$ comodulation of airway smooth muscle remodeling in severe asthma. Am. J. Physiol. Lung Cell. Mol. Physiol. 2019, 316, L843-L868. [CrossRef] [PubMed]

82. Al-Alwan, L.A.; Chang, Y.; Baglole, C.J.; Risse, P.; Halayko, A.J.; Martin, J.G.; Eidelman, D.H.; Hamid, Q. Autocrine-regulated airway smooth muscle cell migration is dependent on IL-17-induced growth-related oncogenes. J. Allergy Clin. Immunol. 2012, 130, 977-985.e6. [CrossRef]

83. Al-Alwan, L.A.; Chang, Y.; Mogas, A.; Halayko, A.J.; Baglole, C.J.; Martin, J.G.; Rousseau, S.; Eidelman, D.H.; Hamid, Q. Differential roles of CXCL2 and CXCL3 and their receptors in regulating normal and asthmatic airway smooth muscle cell migration. J. Immunol. 2013, 191, 2731-2741. [CrossRef]

84. Ji, X.; Li, J.; Xu, L.; Wang, W.; Luo, M.; Luo, S.; Ma, L.; Li, K.; Gong, S.; He, L.; et al. IL4 and IL-17A provide a Th2/Th17-polarized inflammatory milieu in favor of TGF- $\beta_{1}$ to induce bronchial epithelial-mesenchymal transition (EMT). Int. J. Clin. Exp. Pathol. 2013, 6, 1481-1492.

85. Zhang, Y.; Jing, Y.; Qiao, J.; Luan, B.; Wang, X.; Wang, L.; Song, Z. Activation of the mTOR signaling pathway is required for asthma onset. Sci. Rep. 2017, 7, 4532. [CrossRef]

86. Liu, A.; Wu, J.; Li, A.; Bi, W.; Liu, T.; Cao, L.; Liu, Y.; Dong, L. The inhibitory mechanism of Cordyceps sinensis on cigarette smoke extract-induced senescence in human bronchial epithelial cells. Int. J. Chron. Obstruct. Pulmon. Dis. 2016, 11, 1721-1731. [PubMed]

87. Wang, Z.; Su, R.; Yang, B.; Yang, K.; Yang, L.; Yan, Y.; Chen, Z. Potential role of cellular senescence in asthma. Front. Cell Dev. Biol. 2020, 8, 59. [CrossRef]

88. Athari, S.S. Targeting cell signaling in allergic asthma. Signal. Transduct. Target. Ther. 2019, 4, 45. [CrossRef] [PubMed]

89. Zou, W.; Zou, Y.; Zhao, Z.; Li, B.; Ran, P. Nicotine-induced epithelial-mesenchymal transition via Wnt/ $\beta$-catenin signaling in human airway epithelial cells. Am. J. Physiol. Lung Cell. Mol. Physiol. 2013, 304, L199-L209. [CrossRef] [PubMed]

90. Zhang, X.; Ma, X.; Xu, Y.; Liu, X.; Zhang, Z. The effect of cigarette smoke extract on the proliferation of human airway smooth muscle cells sensitized by serum from bronchial asthmatic patients. ZhonghuaJie He He Hu Xi Za Zhi 2011, 34, 604-608.

91. Ijaz, T.; Pazdrak, K.; Kalita, M.; Konig, R.; Choudhary, S.; Tian, B.; Boldogh, I.; Brasier, A.R. Systems biology approaches to understanding Epithelial Mesenchymal Transition (EMT) in mucosal remodeling and signaling in asthma. World Allergy Org. J. 2014, 7, 13. [CrossRef] [PubMed]

92. Pan, Y.; Liu, L.; Li, S.; Wang, K.; Ke, R.; Shi, W.; Wang, J.; Yan, X.; Zhang, Q.; Wang, Q.; et al. Activation of AMPK inhibits TGF- $\beta 1$-induced airway smooth muscle cells proliferation and its potential mechanisms. Sci. Rep. 2018, 8, 3624. [CrossRef]

93. Zhou, X.; Tu, J.; Li, Q.; Kolosov, V.P.; Perelman, J.M. Hypoxia induces mucin expression and secretion in human bronchial epithelial cells. Transl. Res. 2012, 160, 419-427. [CrossRef]

94. Lee, S.Y.; Kwon, S.; Kim, K.H.; Moon, H.S.; Song, J.S.; Park, S.H.; Kim, Y.K. Expression of vascular endothelial growth factor and hypoxia-inducible factor in the airway of asthmatic patients. Ann. Allergy Asthma Immunol. 2006, 97, 794-799. [CrossRef]

95. Wu, S.; Li, H.; Yu, L.; Wang, N.; Li, X.; Chen, W. IL-1 $\beta$ upregulates Muc5ac expression via NF-kB-induced HIF- $1 \alpha$ in asthma. Immunol. Lett. 2017, 192, 20-26. [CrossRef] [PubMed]

96. Zhang, C.; Qin, S.; Qin, L.; Liu, L.; Sun, W.; Li, X.; Li, N.; Wu, R.; Wang, X. Cigarette smoke extract-induced p120-mediated NF-kB activation in human epithelial cells is dependent on the RhoA/ROCK pathway. Sci. Rep. 2016, 6, 23131. [CrossRef]

97. Zhang, Y.; Saradna, A.; Ratan, R.; Ke, X.; Tu, W.; Do, D.C.; Hu, C.; Gao, P. RhoA/Rho-kinases in asthma: From pathogenesis to therapeutic targets. Clin. Transl. Immunol. 2020, 9, e1134. [CrossRef]

98. Ji, M.; Zhang, Y.; Li, N.; Wang, C.; Xia, R.; Zhang, Z.; Wang, S. Nicotine component of cigarette smoke extract (CSE) decreases the cytotoxicity of CSE in BEAS-2B cells stably expressing human cytochrome P450 2A13. Int. J. Environ. Res. Public Health 2017, 14, 1221. [CrossRef] [PubMed] 
99. Schwalm, K.; Stevens, J.F.; Jiang, Z.; Schuyler, M.R.; Schrader, R.; Randell, S.H.; Green, F.H.; Tesfaigzi, Y. Expression of the pro-apoptotic protein bax is reduced in bronchial mucous cells of asthmatics. Am. J. Physiol. Lung Cell. Mol. Physiol. 2008, 294, L1102-L1109. [CrossRef]

100. Liu, X.; Conner, H.; Kobayashi, T.; Kim, H.; Wen, F.; Abe, S.; Fang, Q.; Wang, X.; Hashimoto, M.; Bitterman, P.; et al. Cigarette smoke extract induces DNA damage but not apoptosis in human bronchial epithelial cells. Am. J. Respir. Cell Mol. Biol. 2005, 33, 121-129. [CrossRef]

101. Zaffini, R.; Gotte, G.; Menegazzi, M. Asthma and poly(ADP-ribose) polymerase inhibition: A new therapeutic approach. Drug Des. Devel. Ther. 2018, 12, 281-293. [CrossRef] [PubMed]

102. Bucchieri, F.; Gammazza, A.M.; Pitruzzella, A.; Fucarino, A.; Farina, F.; Howarth, P.; Holgate, S.T.; Zummo, G.; Davies, D.E. Cigarette smoke causes caspase-independent apoptosis of bronchial epithelial cells from asthmatic donors. PLoS ONE 2015, 10, e0120510. [CrossRef] [PubMed]

103. Bergeron, C.; Boulet, L.; Page, N.; Laviolette, M.; Zimmermann, N.; Rothenberg, M.E.; Hamid, Q. Influence of cigarette smoke on the arginine pathway in asthmatic airways: Increased expression of arginase I. J. Allergy Clin. Immunol. 2007, 119, 391-397. [CrossRef] [PubMed]

104. Prado, C.M.; Martins, M.A.; Tibério, I.F.L.C. Nitric oxide in asthma physiopathology. ISRN Allergy 2011, 2011, 832560. [CrossRef]

105. Xu, T.; Ge, X.; Lu, C.; Dai, W.; Chen, H.; Xiao, Z.; Wu, L.; Liang, G.; Ying, S.; Zhang, Y.; et al. Baicalein attenuates OVA-induced allergic airway inflammation through the inhibition of the NF-кB signaling pathway. Aging 2019, 11, 9310-9327. [CrossRef]

106. Dong, S.; Zhong, Y.; Lu, W.; Li, G.; Jiang, H.; Mao, B. Baicalin Inhibits Lipopolysaccharide-Induced Inflammation Through Signaling NF-kB Pathway in HBE16 Airway Epithelial Cells. Inflammation 2015, 38, 1493-1501. [CrossRef] [PubMed]

107. Al-Muhsen, S.; Johnson, J.R.; Hamid, Q. Remodeling in asthma. J. Allergy Clin. Immunol. 2011, 128, 451-462. [CrossRef] [PubMed]

108. Michalik, M.; Wójcik-Pszczoła, K.; Paw, M.; Wnuk, D.; Koczurkiewicz, P.; Sanak, M.; Pękala, E.; Madeja, Z. Fibroblast-tomyofibroblast transition in bronchial asthma. Cell. Mol. Life Sci. 2018, 75, 3943-3961. [CrossRef] [PubMed]

109. Ryszawy, D.; Rolski, F.; Ryczek, K.; Catapano, J.; Wróbel, T.; Michalik, M.; Czyż, J. Invasive bronchial fibroblasts derived from asthmatic patients activate lung cancer A549 cells in vitro. Oncol. Lett. 2018, 16, 6582-6588. [CrossRef]

110. Wong, A.W.; Ryerson, C.J.; Guler, S.A. Progression of fibrosing interstitial lung disease. Respir. Res. 2020, 21, 32. [CrossRef]

111. Li, J.; Yang, M.; Li, P.; Su, Z.; Gao, P.; Zhang, J. Idiopathic pulmonary fibrosis will increase the risk of lung cancer. Chin. Med. J. 2014, 127, 3142-3149. [PubMed]

112. Ballester, B.; Milara, J.; Cortijo, J. Idiopathic pulmonary fibrosis and lung cancer: Mechanisms and molecular targets. Int. J. Mol. Sci. 2019, 20, 593. [CrossRef] [PubMed] 